\title{
Second-order analysis of a steel truss structure for the Hydropower Plant Dravograd
}

\author{
S. Kravanja \\ Faculty of Civil Engineering, Transportation Engineering \\ and Architecture, University of Maribor, Slovenia
}

\begin{abstract}
The paper presents the second-order analysis of a truss girder for the Hydropower Plant Dravograd, Slovenia. The existing steel girder of the span of $24.5 \mathrm{~m}$ was constructed 75 years ago for the reconstruction of spillways. The girder was designed according to old German DIN standards. The linear global analysis of structure was performed together with dimensioning.

Since the water elevation (and consequently the water load) on the Drava River, has increased in last years (a flood occurred with the most extreme/highest water elevation in history), a special structural analysis was requested to be done, which should show the resistance of the steel structure in new conditions. After all dimensions of the structure were checked and measured, the finite element model of the structure was modelled. Steel grade St 37 was considered. The self-weight, a hydrostatic load and a friction force between the truss girder and sealing I-beams were taken into account. Computer program SAP 2000 was used and the secondorder FE analysis was performed. Dimensioning was made according to Eurocode 3. It was found that the truss girder at the HP Dravograd will not resist a new water load of the Drava River successfully (the water elevation of $331.90 \mathrm{~m}$ ). While the resistance of the structure is 4.25 -times exceeded, the structure connections are 7.64-times overloaded.

To overcome the problem, an allowable water load on the truss structure was calculated. The highest possible downstream water elevation of $329.55 \mathrm{~m}$ was consequently determined which the girder structure can be successfully subjected to.
\end{abstract}

Keywords: steel structures, truss girder, second-order FE analysis, hydropower plant. 


\section{Introduction}

The paper deals with the second-order analysis of an existing steel truss girder for the Hydropower Plant Dravograd, Slovenia. The girder was constructed 75 years ago for the case of the reconstruction of spillways. It was designed according to old German DIN standards: a simple linear global analysis was performed together with dimensioning.

Company DEM, the largest Slovenian producer of electric power, planned to reconstruct the old Hydropower Plant Dravograd, which was constructed during the World War II. The construction began in 1941 and was completed in 1944 with two units installed [1]. The HP Dravograd is designed as the first pier-type power plant in Europe along with a similar plant in Lavamünd, Austria. In April 1945 allied air raids caused considerable damage to the power plant. After the war intensive renewal, operations began and with the launch of the last (third) unit in 1955 , construction of the power plant was completed. The last comprehensive refurbishment of the units was completed in 1994.

The actual planed reconstruction of the HP Dravograd comprises also the refurbishment of spillways. Before this refurbishment, a problem occurred, because the water elevation of the Drava River and consequently the water load on the structure were significantly increased in last years; a flood occurred with the extreme/highest water elevation in history.

Increased water discharges in the Drava River basin caused a major natural disaster on 5th and 6th November 2012 [2]. Drava flooded the areas along its entire stream from Dravograd to the national border with Croatia. The flood wave affected residential areas, agricultural land, and road and water infrastructure. The entire flow of the Drava River increased to reach a record of $3300 \mathrm{~m}^{3} / \mathrm{s}$. There are constructed eight hydropower plants on Drava River in Slovenia, installed to the average year flow of $450 \mathrm{~m}^{3} / \mathrm{s}$, and three small hydropower plants. The structures of hydropower plants were not damaged, except the diversion canal of the Formin hydroelectric power plant.

Four spillways at the HP Dravograd, each $24 \mathrm{~m}$ wide [3], are planned to be reconstructed one by one. In order to empty the water in spillway for the reconstruction, the upstream water (the left higher water on Figure 1) has to be closed by double hook gates and the downstream water (the right lower water on Figure 1) has to be temporary closed by the steel truss girder ("W" girder on the right side on Figure 1), which is placed over the spillway together with vertical steel I-beams, which seal the downstream water.

The existing $24.50 \mathrm{~m}$ long steel truss girder, which was constructed 75 years ago for the reconstruction of spillways, had to be checked for the resistance in new conditions. It must resist a load of $6.90 \mathrm{~m}$ of water column, occurred at a new water elevation of $331.90 \mathrm{~m}$. A new global analysis and dimensioning of the girder was made at the Faculty of Civil Engineering, University of Maribor, in 2013 [4]. 


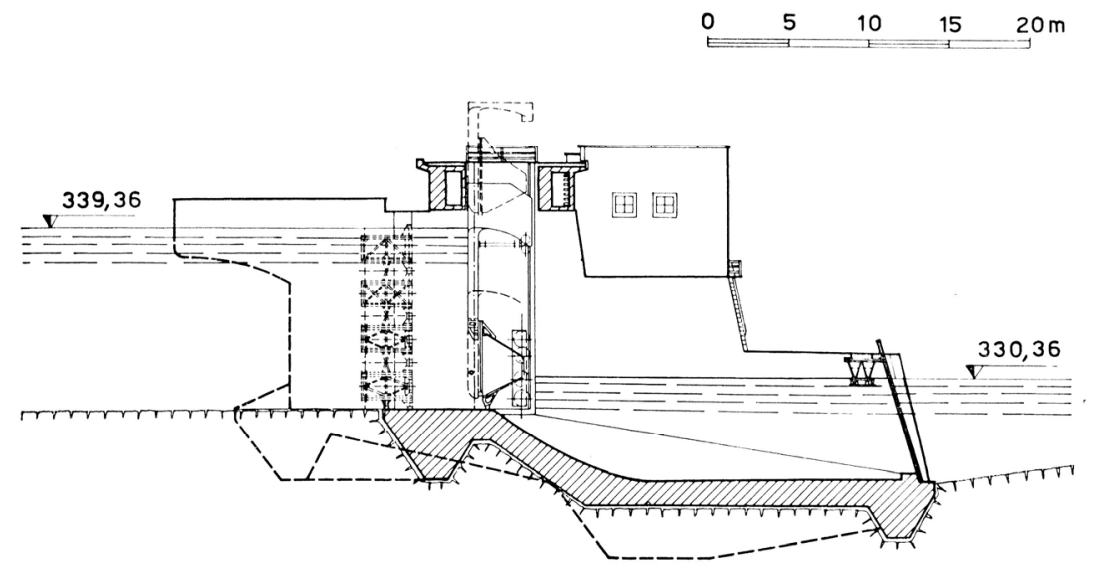

Figure 1: Cross-section through the HP Dravograd spillways [3].

\section{Truss girder}

Project documentation for the girder was drawn in 1939. The girder was constructed some years later as a $24.5 \mathrm{~m}$ long 3-D truss steel structure. It comprises two box supports, a $2100 \mathrm{~mm}$ wide upper frame, a $1230 \mathrm{~mm}$ wide lower frame (see Figure 2) and nine $1400 \mathrm{~mm}$ high trapezoidal cross frames (see Figure 3). Steel elements (chords, diagonals, verticals) were made from I, [ and $L$ standard sections and plate sheets, connected together with rivets. Three approx. $8 \mathrm{~m}$ long truss parts were riveted in a factory, transported to the HP Dravograd ground and connected together with bolts into entire girder.

The project documentation of the girder from 1939 is not complete. Stress calculation is missing. Steel grade is unknown. The design water load taken for the calculation is also unknown. The task was thus to check the resistance of the girder made from steel materials, which were mostly used in 1939 [5]:

- Steel St 37 (DIN 17100 [5]) with $f_{y}=24.0 \mathrm{kN} / \mathrm{cm}^{2}$ (yield strength) and $f_{u}=$ $37.0 \mathrm{kN} / \mathrm{cm}^{2}$ (tensile strength),

- Rivets TUSt 34 (DIN 17110 [5]) with $f_{u r}=34.0 \mathrm{kN} / \mathrm{cm}^{2}$ and

- Bolts 4S ( 4.6, DIN 267 [5]) with $f_{u b}=40.0 \mathrm{kN} / \mathrm{cm}^{2}$.

Global dimensions of the girder, steel sections and connections were checked. The measured dimensions differ from those from the documentation for a few millimetres only. It was found that the girder is still in good condition. 
54 High Performance and Optimum Design of Structures and Materials II
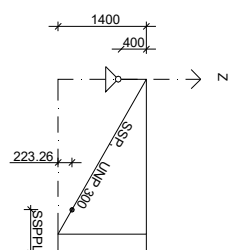

共
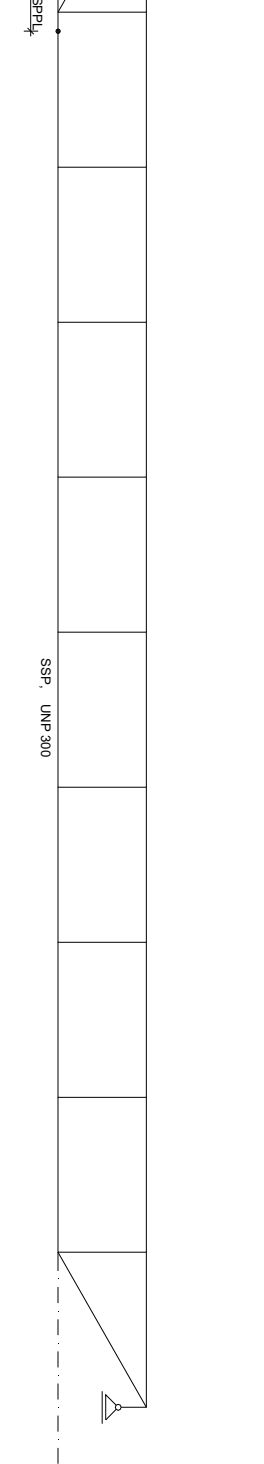
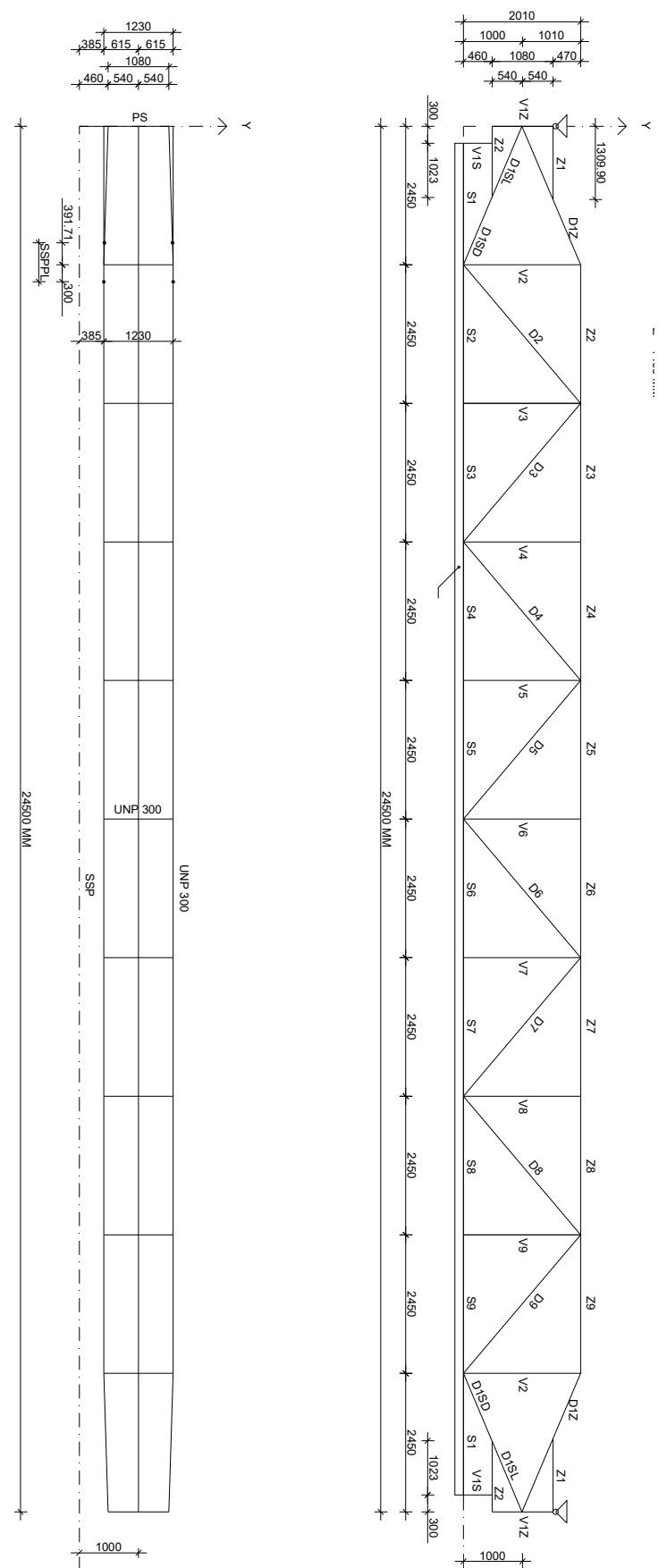

Figure 2: Longitudinal cross-section, the lower frame and the upper frame of the truss girder (from left to right). 


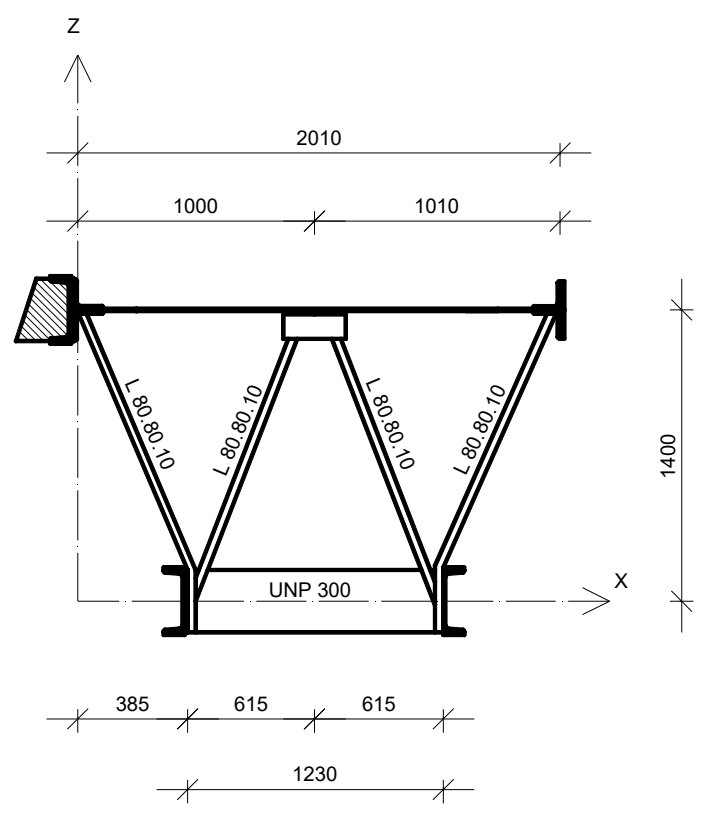

Figure 3: Trapezoidal cross frame of the girder.

\section{Hydrostatic water load}

The girder has to be checked for the combined effect of the structure self-weight and a hydrostatic load of $6.9 \mathrm{~m}$ of water column, caused by the downstream water elevation of $331.90 \mathrm{~m}$ and $0.25 \mathrm{~m}$ high waves (see Figure 4).

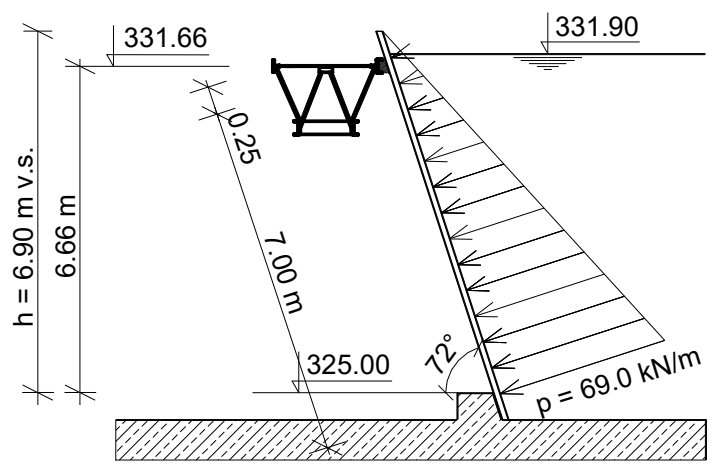

Figure 4: Steel truss girder and the sealing I-beams.

The hydrostatic load is transmitted to the truss girder as an upper action $R_{z g}$ (see Figure 5) from the sealing steel I-beams, which are placed on the spillway sill side by side with a 72 degree inclination in order to seal the spillway. 


$$
R_{z g}=\frac{\frac{p \cdot L_{t o t}}{2} \cdot \frac{L_{t o t}}{3}}{L}=\frac{\frac{69.0 \cdot 7.25}{2} \cdot \frac{7.25}{3}}{7.25}=86.353 \mathrm{kN} / \mathrm{m}^{1}
$$

This water load is partitioned into its horizontal and vertical components:
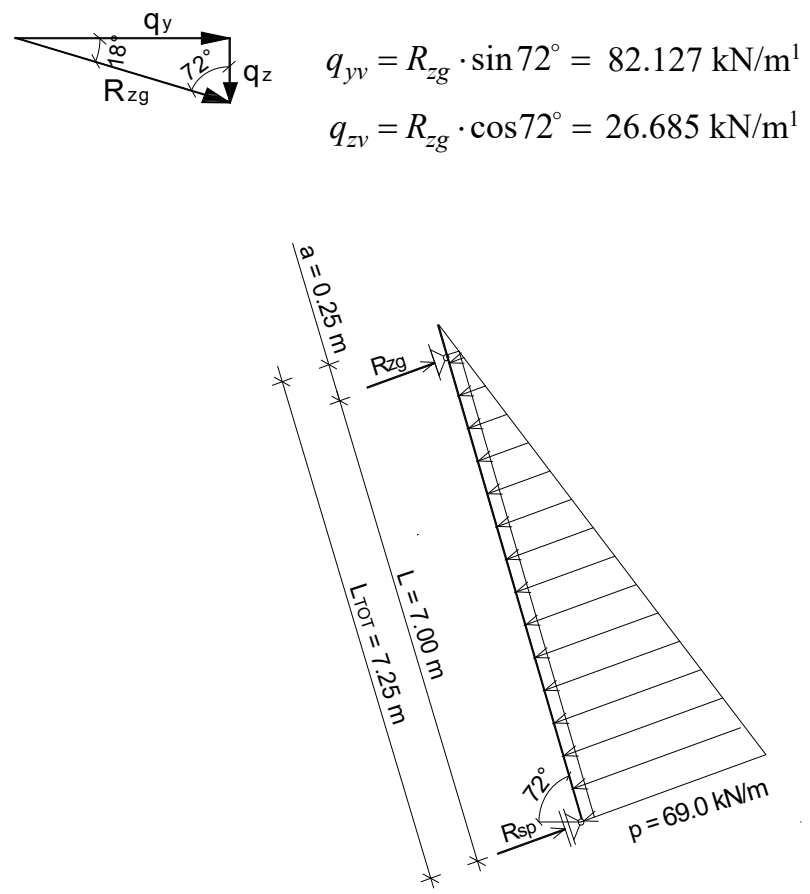

Figure 5: Hydrostatic load on the sealing I-section beams.

\section{Friction force}

The sealing I-beams act on the truss girder with the water action $R_{z g}$. In a longitudinal joint between the truss girder and the sealing I-beams, a friction force is occurred. It acts in the opposite direction to the motion of girder, caused by the girder deflection due to the self-weight and the water load $R=R_{z g}$.

In the case, when the vertical displacements of the girder $\delta_{\mathrm{v}}$ are greater than the horizontal ones $\delta_{\mathrm{h}}$ (and this is here the actual case, proved by the FE analysis), the friction force is directed upwards (see Figure 6).

Since the sealing steel I-beams are in the contact with the truss girder over a longitudinal wooden beam, placed into the longitudinal girder's upper chord channel section, a friction coefficient $v$ between wood and steel is defined to be 0.2 , see [6-8]. The friction force $T$ is calculated according to Eq. (4):

$$
T=R \cdot v=86.353 \cdot 0.2=17.271 \mathrm{kN} / \mathrm{m}^{1}
$$




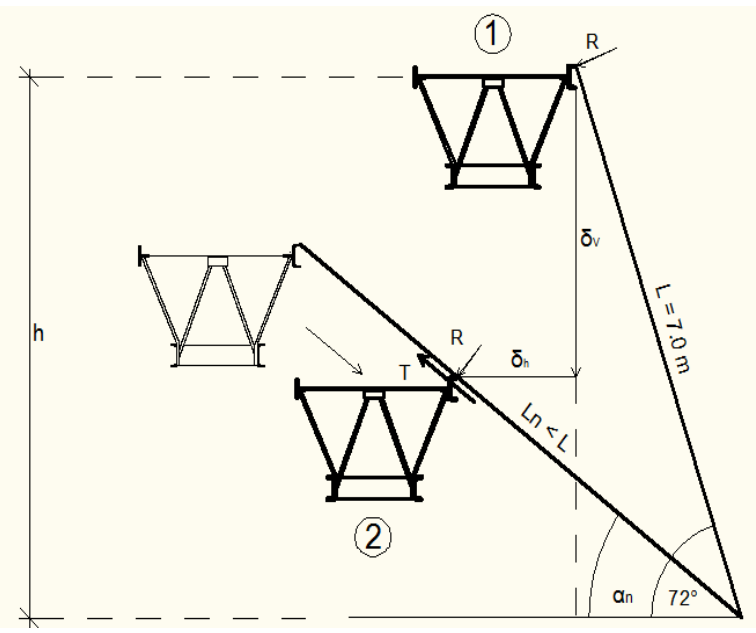

Figure 6: Deflections $\delta_{\mathrm{v}}$ and $\delta_{\mathrm{h}}$ of the truss girder and the direction of friction.

The friction force components are calculated according to Eqs (5) and (6). Horizontal and vertical components of the water load and the friction force can now be summed. They are shown in Figure 7.

$$
\begin{aligned}
& T_{y}=T \cdot \cos 72^{\circ}=5.337 \mathrm{kN} / \mathrm{m}^{1} \\
& T_{z}=T \cdot \sin 72^{\circ}=16.426 \mathrm{kN} / \mathrm{m}^{1}
\end{aligned}
$$

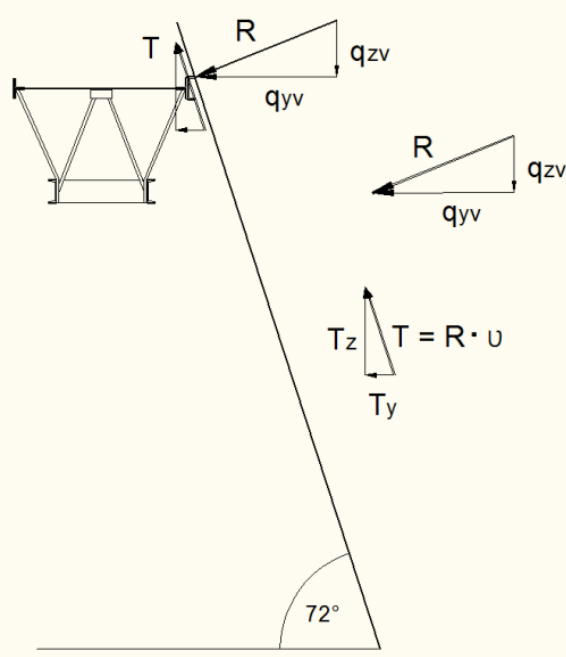

Figure 7: Horizontal and vertical components of the water load and friction. 
The horizontal load on the truss girder is increased, because both the horizontal components, the horizontal component of the water load and the horizontal component of the friction force have the same direction, see Eq. (7):

$$
q_{y}=q_{y v}+T_{y}=82.127+5.337=\underline{87.464 \mathrm{kN} / \mathrm{m}^{1}}
$$

The vertical load on the girder is decreased due to the upper direction of the vertical friction component, see $\mathrm{Eq}(8)$ :

$$
q_{z}=q_{z v}-T_{z}=26.685-16.426=\underline{10.259 \mathrm{kN} / \mathrm{m}^{1}}
$$

It should be noted that the friction between the truss girder and the sealing Ibeams increases the horizontal load on the girder for only $6.5 \%$, while the vertical load is decreased for $61.5 \%$.

\section{Second-order FE analysis and dimensioning}

After loads on the truss girder were defined, a FE model of the structure was modelled. A computer program SAP 2000 was applied. While beam finite elements were used for chords and bracing members, shell finite elements were assigned for plate sheets. The measured dimensions of the girder and the measured cross-sections of the members were used rather than those from the project documentation. Effective widths of the subjected plate sheets were calculated and added to complete the member's cross-sections (see Figure 8).
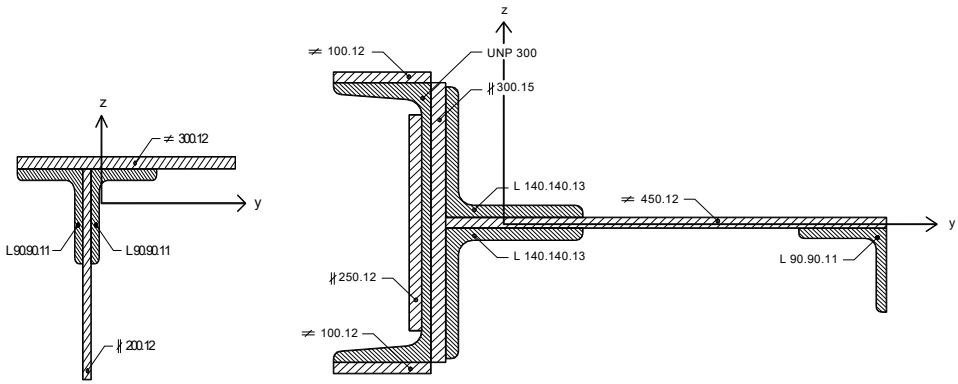

Figure 8: A pair of the combined cross-sections of members.

Steel grade St 37 was considered. The self-weight of the structure, the mentioned load of $6.90 \mathrm{~m}$ of water column and the friction force between the girder and the sealing I-beams were taken into account.

The following safety factors were considered:

- Partial factor for actions $\gamma_{f}=1.35$ (Eurocode),

- Partial factor for resistance $\gamma_{M}=1.20$, which includes weak/net cross-sections because of rivets and bolts, a worse buckling curve because of rivets, an effect of torsional moment because of eccentricity of the water load $R$ on the girder, an influence of the lateral torsional buckling of members and old material,

- Common safety factor $\gamma=1.62$ (see Eq. (9)).

$$
\gamma=\gamma_{f} \cdot \gamma_{M}=1.35 \cdot 1.20=1.62
$$




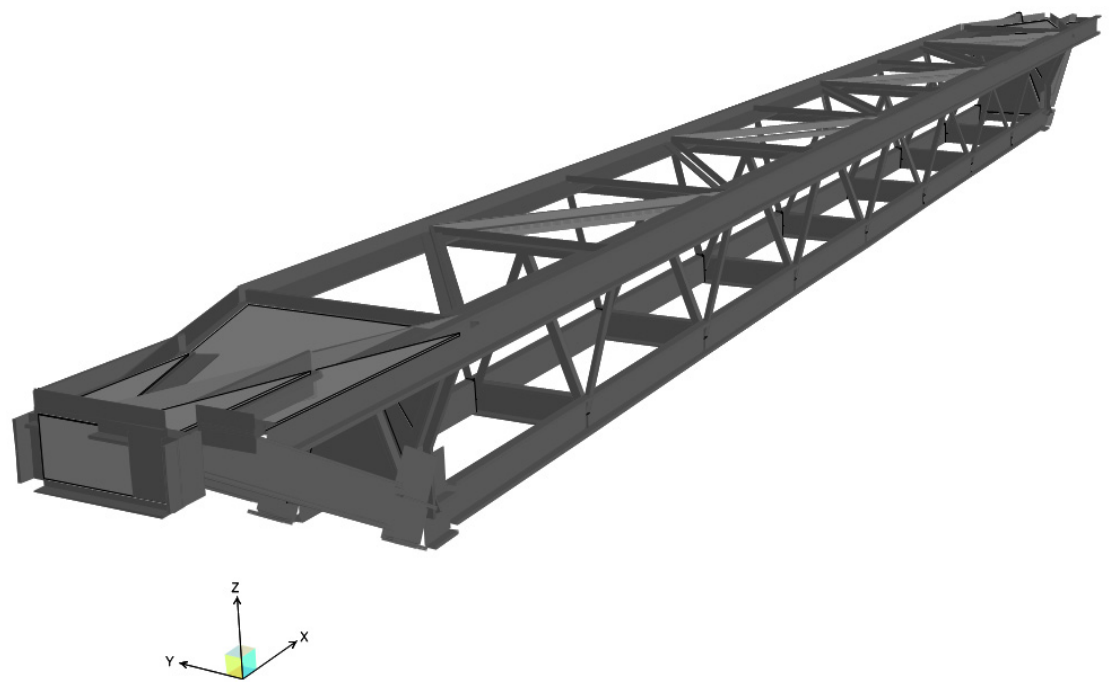

Figure 9: The modelled truss girder.

The second-order analysis of the structure, including the P- $\Delta$ effect, was performed. Since the second-order analysis accurate, it was applied for this study and dimensioning. Inner forces, stresses and deflections were calculated and drawn (see Figures 10-13).

Dimensioning was performed with SAP 2000 according to Eurocode 3. The tensile, compress, shear and bending resistances of cross-sections were checked as well as the buckling and lateral torsional buckling resistances of steel members, see Eqs (10) and (11).

$$
\frac{N_{E d}}{\chi_{y} \frac{A f_{y}}{\gamma_{M 1}}}+k_{y y} \frac{\mathrm{M}_{\mathrm{y}, \mathrm{Ed}}}{\chi_{L T} \frac{\mathrm{W}_{\mathrm{y}} f_{y}}{\gamma_{M 1}}}+k_{y z} \frac{\mathrm{M}_{\mathrm{z}, \mathrm{Ed}}}{\frac{\mathrm{W}_{\mathrm{z}} f_{y}}{\gamma_{M 1}}} \leq 1,0
$$

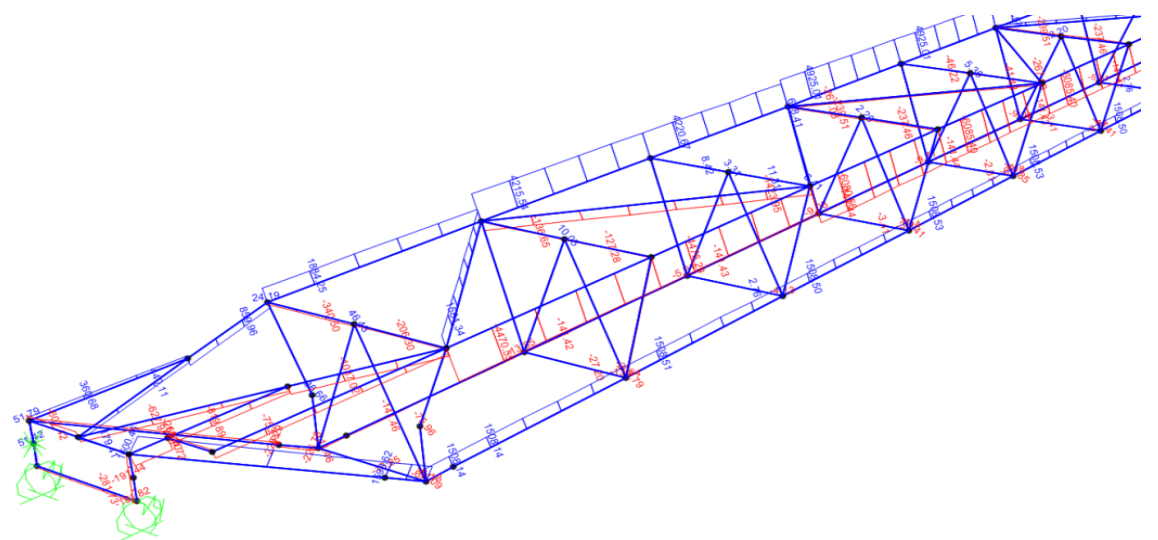

Figure 10: Axial forces. 


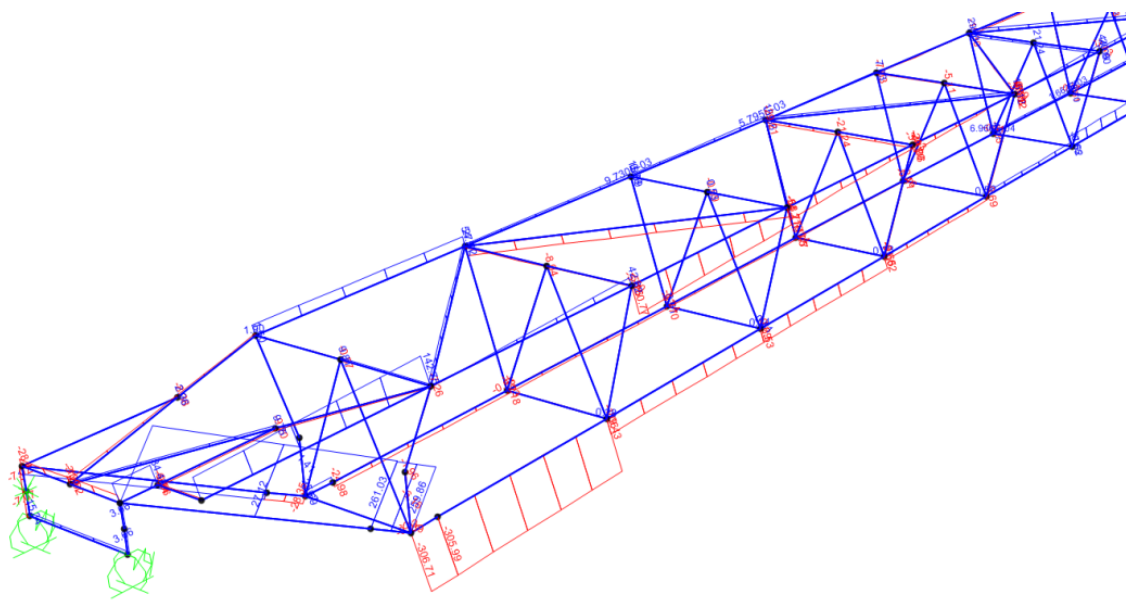

Figure 11: Shear forces.

$$
\frac{N_{E d}}{\chi_{z} \frac{A f_{y}}{\gamma_{M 1}}}+k_{z y} \frac{\mathrm{M}_{\mathrm{y}, \mathrm{Ed}}}{\chi_{L T} \frac{\mathrm{W}_{\mathrm{y}} f_{y}}{\gamma_{M 1}}}+k_{z z} \frac{\mathrm{M}_{\mathrm{z}, \mathrm{Ed}}}{\frac{\mathrm{W}_{\mathrm{z}} f_{y}}{\gamma_{M 1}}} \leq 1,0
$$

The maximal vertical deflection of the structure was calculated: $0.2516 \mathrm{~m}$ (see Figure 14).

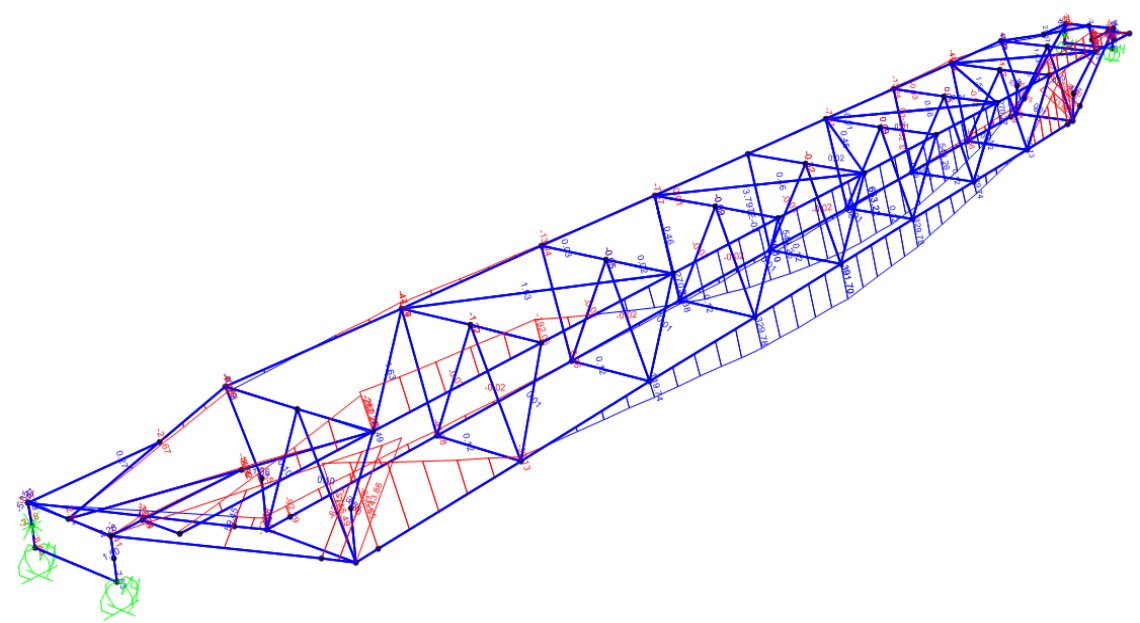

Figure 12: Bending moments.

Non-dimensional resistance factors, which should be lower than 1.0 (see Eqs (10) and (11)) were calculated. The maximal resistance factor was calculated in a diagonal close to the origin of the lower chord and was 4.25. The resistance of the girder is therefore 4.25-times exceeded, if it is subjected to the load of $6.90 \mathrm{~m}$ of water column (the water elevation of $331.90 \mathrm{~m}$ ). 


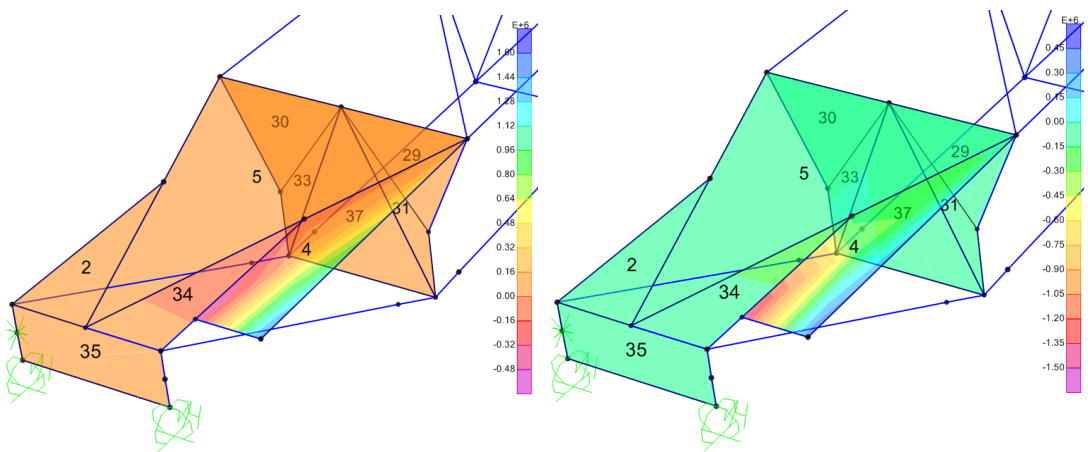

Figure 13: Maximal and minimal stresses in edge plate elements.

The first-order analysis of the structure was performed for the comparison. The second-order analysis exhibits $60 \%$ lower resistance than the first-order one, particularly because of large vertical deflections and large compress forces in the upper chord. The resistance of connections was also not sufficient and was in the most problematic section 7.64-times exceeded.

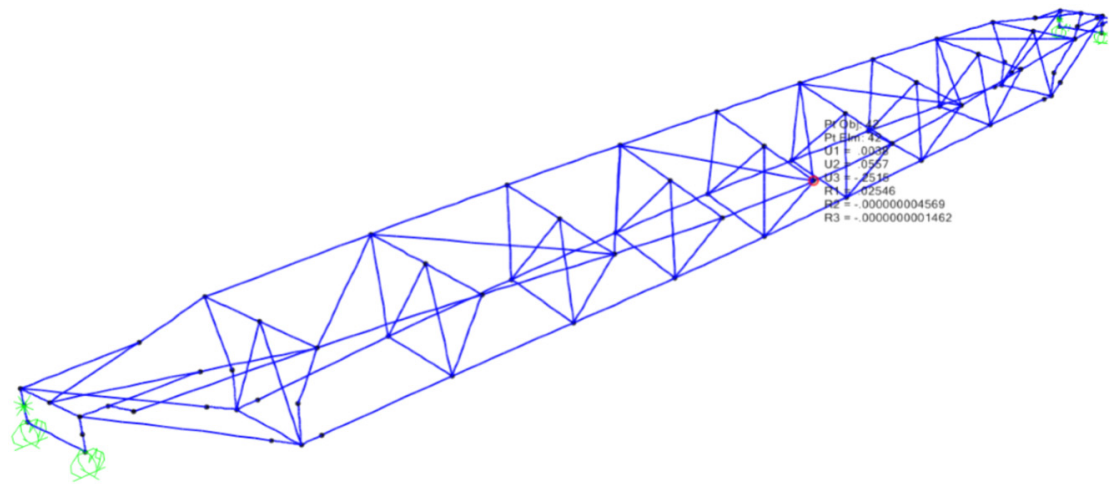

Figure 14: Maximal vertical deflection of the girder.

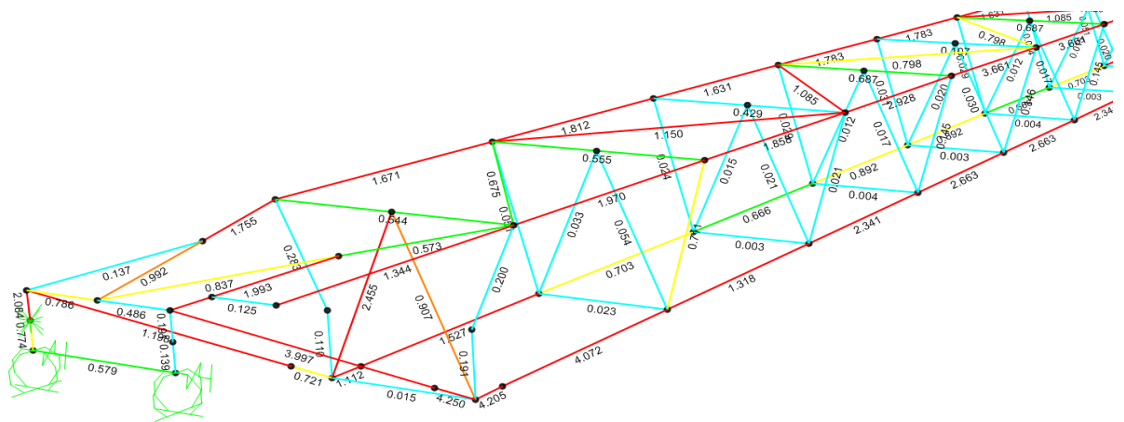

Figure 15: Resistances of members of the girder. 


\section{Conclusions}

We may conclude that the truss girder at the HP Dravograd will not resist successfully a new water load of the Drava River (the water elevation of $331.90 \mathrm{~m}$ ). While the resistance of the structure is 4.25 -times exceeded, the structure connections are 7.64-times overloaded.

In order to overcome this problem, an allowable (the highest possible) water load on the truss structure had to be determined. It was calculated that the girder exhibits a sufficient resistance for the 3.89-times lower water load than mentioned above. In this way, determined was an allowable downstream water elevation of $329.55 \mathrm{~m}$ to which the girder structure can be subjected (see Figure 16).

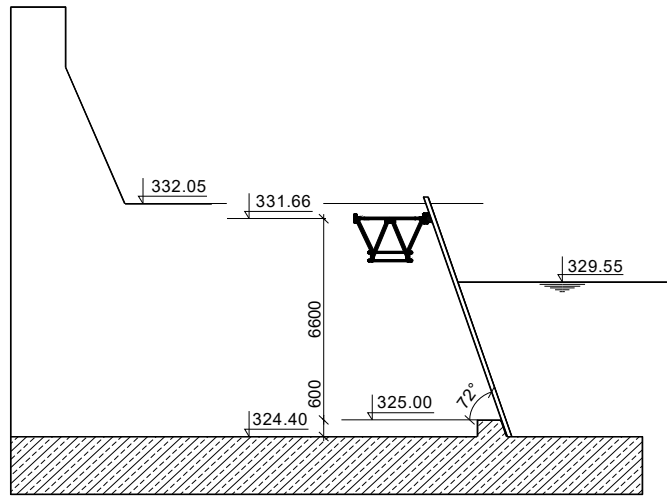

Figure 16: Allowable water elevation of the downstream water.

\section{References}

[1] DEM, http: //www.dem.si/en-gb/Power-plants-and-generation Power-plants/ Dravograd-HPP.

[2] Klaneček, M., 5 November 2012 Floods in the Drava River Basin (Poplave 5. novembra 2012 v porečju Drave), UJMA, 27, pp. 52-61, 2013.

[3] Dravske elektrarne (Hydropower Plants on the Drava River), ELES, Ljubljana, 1963.

[4] Kravanja, S., Žula, T., Križaj, R., Statični izračun nosilca tesnilnih igel na HE Dravograd (Global analysis and dimensioning of the truss girder for the HP Dravograd), Faculty of Civil Engineering, University of Maribor, 2013.

[5] Stahl im Hochbau, Handbuch für Entwurf, Berechnung und Ausführung von Stahlbauten, 13. Auflage, Verlag Stahleisen M.B.H., Düsseldorf, 1967.

[6] The Engineering ToolBox (www.EngineeringToolBox.com), 2013.

[7] Gorst, N.J.S., Williamson, S.J., Pallett, P.F., Clark L.A., Friction in temporary works, Health and Safety Executive, HSE Books, Sudbury, Suffolk, United Kingdom, 2003.

[8] Meng, Q-J, Hirai, T., Koizumi A, Frictional Coefficients between Timber and Other Structural Materials, Journal of the Japan Wood Research Society, 54(5), pp. 281-288, 2008.

[9] Eurocode 3: Design of steel structures, EN 1993. 